\title{
Soil Contamination with Copper and its Effect on Selected Soil Properties After Applying Neutralizing Substances
}

\author{
Mirosław Wyszkowski* \\ Department of Environmental Chemistry, University of Warmia and Mazury in Olsztyn, Olsztyn, Poland
}

Received: 23 January 2018

Accepted: 23 April 2018

\begin{abstract}
The aim of this study was to determine the effects of copper contamination $(0,50,100,150$, and $200 \mathrm{mg} \mathrm{Cu} / \mathrm{kg}$ of soil) and neutralising substances on the content of total organic carbon, total nitrogen, available forms of phosphorus, potassium, and magnesium, and C:N ratio in soil. The experiment was conducted in four series: without neutralising substances and with compost $3 \%$ of soil weight, bentonite $2 \%$ of soil weight, and zeolite $2 \%$ of soil weight. Contamination of soil with copper and the application of the neutralising substances had a significant effect on soil properties. Contamination with copper in the series without substances increased the content of total nitrogen and available phosphorus, potassium, and especially magnesium. Copper also widened the C:N ratio in soil. All of the amendments applied to the soil had the strongest effect on the content of total nitrogen and the $\mathrm{C}: \mathrm{N}$ ratio in soil. They reduced the content of total nitrogen and widened the $\mathrm{C}: \mathrm{N}$ ratio. Amendments also increased the content of available magnesium in soil. The effect of the substances applied to soil on the content of the other elements was significantly weaker, as it changed by up to $12 \%$.
\end{abstract}

Keywords: soil pollution, compost, bentonite, zeolite, soil properties

\section{Introduction}

Growing industrialisation frequently leads to excessive environmental pollution and to irreversible or hardly reversible changes of its status [1-2]. A particular hazard to the soil environment is created by contamination, which is followed by the transfer of contaminants to plants growing on the soils and further parts of the food chain [3]. Trace metals are one of the most hazardous contaminants in the environment.

*e-mail: miroslaw.wyszkowski@uwm.edu.pl
They change soil properties [4], especially its microbiological and biochemical properties [5], thereby creating disruption in transformations and circulation of elements in the environment $[3,6]$. This can lead to limiting the absorption of essential micronutrients and to excessive accumulation of contaminants in crops [7]. This is extremely important in terms of the production of good quality food. Copper is one of the elements that can accumulate in soil in excessive amounts. Its presence in the soil can be a consequence of industrial pollution deposited in the ground, but it can also result from prolonged intensive fertilisation [1]. The content of cobalt in fen soils and limestone soils was higher than in sandy podzolic soils [8]. Copper plays a dual role in 
organisms. It is essential to the life and development of many organisms as it takes part in many physiological processes, including photosynthesis and respiration, usually as a component of many enzymes [9]. Excessive amounts of copper can restrict the growth of plants by having an adverse effect on yield and quality [10], and it causes diseases in humans and animals [11]. Therefore, it is important to maintain the optimum concentrations of copper in soil and to limit its absorption by plants if its level in soil increases excessively [3, 12]. Apart from phytoremediation [13], one of the "in situ" methods involves applying different substances in the soil, whose aim is to limit or neutralise the effect of contaminants [14-16]. Organic substances, bentonite, and zeolite are limiting the uptake of trace elements by plants from soil [17]. The sources, forms, mobility and effects of copper contamination and amendments on soil properties were presented in earlier publications [3, 18].

The aim of this study was to determine the effect of copper contamination on the content of total organic carbon, total nitrogen, available forms of phosphorus, potassium, and magnesium, and $\mathrm{C}: \mathrm{N}$ ratio in soil. The effect of copper on these soil properties was reduced by using compost, bentonite, and zeolite.

\section{Materials and Methods}

The study was based on an experiment conducted in the greenhouse at the University of Warmia and Mazury, Olsztyn (northeastern Poland) in 2012. The experiment was carried out on acidic soil with a granulometric composition of sand (sand fraction, $86 \%$; silt fraction, $12 \%$; clay fraction, $2 \%$ ) according to USDA classification. It had the following properties: $\mathrm{pH} 5.53$ in $1 \mathrm{M} \mathrm{KCl}$; contents of TOC $9.86 \mathrm{~g} / \mathrm{kg}$, total nitrogen $0.71 \mathrm{~g} / \mathrm{kg}, \mathrm{C}: \mathrm{N}$ ratio 13.89 ; and contents of available forms of phosphorus $86.48 \mathrm{mg} / \mathrm{kg}$, potassium $108.46 \mathrm{mg} / \mathrm{kg}$, and magnesium $85.32 \mathrm{mg} / \mathrm{kg}$; and content of total copper $4.24 \mathrm{mg} / \mathrm{kg}$ of soil. The soil was contaminated with copper (as $\mathrm{CaCl}_{2}$ ) at $0,50,100,150$, and $200 \mathrm{mg} \mathrm{Cu} / \mathrm{kg}$ of soil 10 days before sowing. The experiment was carried out in four series: without additives and with compost at $3 \%$ of soil weight, bentonite at $2 \%$ of soil weight, and zeolite at $2 \%$ of soil weight. The concentration of elements in substances was as follows: compost - Corg $204.2 \mathrm{~g} / \mathrm{kg}$, total nitrogen $11.97 \mathrm{~g} / \mathrm{kg}, \mathrm{C}: \mathrm{N}$ ratio 17.06, P $2.39 \mathrm{~g} / \mathrm{kg}, \mathrm{K} 1.41 \mathrm{~g} / \mathrm{kg}, \mathrm{Mg} 1.52 \mathrm{~g} / \mathrm{kg}$, $\mathrm{Cu} 0.81 \mathrm{mg} / \mathrm{kg}$; bentonite - P $0.52 \mathrm{~g} / \mathrm{kg}, \mathrm{K} 2.36 \mathrm{~g} / \mathrm{kg}$, $\mathrm{Mg} \quad 5.04 \mathrm{~g} / \mathrm{kg}, \mathrm{Cu} 21.3 \mathrm{mg} / \mathrm{kg} ;$ and zeolite P $\quad 0.12 \mathrm{~g} / \mathrm{kg}, \quad \mathrm{K} \quad 23.13 \mathrm{~g} / \mathrm{kg}, \quad \mathrm{Mg} \quad 0.37 \mathrm{~g} / \mathrm{kg}, \quad \mathrm{Cu}$ $12.38 \mathrm{mg} / \mathrm{kg}$. The choice of the copper doses to the experiment was dictated according to a regulation of the Minister of the Environment of 9 September 2002 on soil and earth quality standards. The amendments were selected based on previous experiments with other trace elements. Moreover, to satisfy the plants' nutritional needs, fertilisers were added to each pot in the following amounts: $100 \mathrm{mg} \mathrm{N}\left[\mathrm{CO}\left(\mathrm{NH}_{2}\right)_{2}\right]$, $35 \mathrm{mg} \mathrm{P}\left(\mathrm{KH}_{2} \mathrm{PO}_{4}\right), 100 \mathrm{mg} \mathrm{K}\left(\mathrm{KH}_{2} \mathrm{PO}_{4}+\mathrm{KCl}\right), 50 \mathrm{mg}$ $\mathrm{Mg}\left(\mathrm{MgSO}_{4} \cdot 7 \mathrm{H}_{2} \mathrm{O}\right), 0,33 \mathrm{mg} \mathrm{B}\left(\mathrm{H}_{3} \mathrm{BO}_{3}\right), 5 \mathrm{mg} \mathrm{Mn}$ $\left(\mathrm{MnCl}_{2} \cdot 4 \mathrm{H}_{2} \mathrm{O}\right)$, and $5 \mathrm{mg} \mathrm{Mo}\left[\left(\mathrm{NH}_{4}\right)_{6} \mathrm{Mo}_{7} \mathrm{O}_{24} \cdot 4 \mathrm{H}_{2} \mathrm{O}\right]$ per $\mathrm{kg}$ of soil. Copper chloride, compost, bentonite, zeolite, and fertilisers were thoroughly mixed with $9 \mathrm{~kg}$ of soil and transferred into polyethylene pots. In each pot, 8 plants of maize (Zea mays L.) San cultivar were sown on 26 April. The moisture content was maintained at $60 \%$ of the capillary water capacity during the experiment. After 82 days since the start of the experiment (16 July), soil samples for laboratory tests were taken during the maize harvest in the end of tassel emergence - BBCH scale. The experiment was realised in three repetitions (60 pots).

The soil samples were dried and sifted through a $1 \mathrm{~mm}$ mesh sieve. Before starting the experiment the soil, compost, bentonite, and zeolite were mineralized in concentrated nitric acid $\left(\mathrm{HNO}_{3}\right.$ analytically pure) in a MARS 5 microwave oven (CEM Corporation, USA), by the US-EPA3051 method [19]. Content of total copper was determined by flame atomic absorption spectrometry (FAAS). The soil $\mathrm{pH}$ in $1 \mathrm{~mol} / \mathrm{dm}^{3} \mathrm{KCl}$ was determined potentiometrically [20]. The following were determined in the samples (in three replications): organic carbon by the Tiurin method [20], total nitrogen by the Kjeldahl method [20], available forms of phosphorus and potassium by the Egner-Riehm method, and magnesium $(\mathrm{Mg})$ by the Schachtschabel method [20]. Wet mineralisation of the soil samples for total nitrogen was carried out in concentrated sulphuric acid ( $\mathrm{H}_{2} \mathrm{SO}_{4}$ analytically pure). Next, it was analysed in a Buchi K-355 Kjeldahl Distiller. The results were analysed statistically with the STATISTICA software package and a two-way analysis of variance ANOVA. Moreover, the effect of contamination with copper and the impact of compost, bentonite, and zeolite on soil properties was assessed by principal component analysis (PCA) and with Pearson's correlation coefficients [21].

\section{Results and Discussion}

Contamination of the soil with copper and the application of neutralising substances had a significant effect on soil properties (Tables 1-2). Contamination of the soil in the series without amendments increased the content of total nitrogen $(\mathrm{r}=0.441)$ and available phosphorus $(\mathrm{r}=0.808)$, potassium $(\mathrm{r}=0.918)$, and, especially, magnesium $(\mathrm{r}=0.891)$. It also narrowed the $\mathrm{C}: \mathrm{N}$ ratio $(\mathrm{r}=-0.441)$ in soil. The increase in the content of available magnesium in the soil contaminated with $200 \mathrm{mg} \mathrm{Cu} / \mathrm{kg}$ of soil was $49 \%$ and it was greater than that of available potassium (33\%), total nitrogen (24\%), and available phosphorus (20\%), compared to the control (no copper). The organic carbon-to-total nitrogen ratio in the same pot was reduced by $24 \%$.

The greatest effect of all substances was observed in the content of total nitrogen and the $\mathrm{C}: \mathrm{N}$ ratio in soil 
Table 1. Effect of copper contamination and neutralizing substances on content of organic carbon, total nitrogen, and C:N ratio in soil.

\begin{tabular}{|c|c|c|c|c|c|}
\hline Copper dose (mg/kg of soil) & Without amendments & Compost & Bentonite & Zeolite & Average \\
\hline \multicolumn{6}{|c|}{ Organic carbon (g/kg d.m.) } \\
\hline 0 & $9.83 \pm 0.25$ & $9.15 \pm 0.05$ & $8.93 \pm 0.11$ & $8.03 \pm 0.11$ & 8.99 \\
\hline 50 & $9.75 \pm 0.07$ & $9.90 \pm 0.22$ & $8.70 \pm 0.22$ & $8.55 \pm 0.21$ & 9.23 \\
\hline 100 & $9.45 \pm 0.21$ & $9.08 \pm 0.11$ & $9.00 \pm 0.05$ & $8.55 \pm 0.08$ & 9.02 \\
\hline 150 & $9.00 \pm 0.22$ & $9.45 \pm 0.21$ & $8.10 \pm 0.12$ & $8.85 \pm 0.21$ & 8.85 \\
\hline 200 & $9.30 \pm 0.05$ & $8.85 \pm 0.21$ & $7.80 \pm 0.07$ & $8.03 \pm 0.23$ & 8.50 \\
\hline Average & 9.47 & 9.29 & 8.51 & 8.40 & \\
\hline $\mathrm{r}$ & $-0.846^{* *}$ & -0.410 & $-0.853^{* *}$ & 0.131 & $-0.792^{* *}$ \\
\hline$L S D$ for: & \multicolumn{5}{|c|}{$\mathrm{Cu}$ dose - n.s., substances application $-0.53^{* *}$, interaction $-\mathrm{n} . \mathrm{s}^{* *}$} \\
\hline \multicolumn{6}{|c|}{ Total nitrogen (g/kg d.m.) } \\
\hline 0 & $0.80 \pm 0.05$ & $0.48 \pm 0.06$ & $0.60 \pm 0.04$ & $0.50 \pm 0.01$ & 0.60 \\
\hline 50 & $1.10 \pm 0.07$ & $0.63 \pm 0.03$ & $0.44 \pm 0.01$ & $0.52 \pm 0.02$ & 0.67 \\
\hline 100 & $1.13 \pm 0.02$ & $0.68 \pm 0.06$ & $0.51 \pm 0.03$ & $0.53 \pm 0.03$ & 0.71 \\
\hline 150 & $1.10 \pm 0.02$ & $0.53 \pm 0.02$ & $0.66 \pm 0.02$ & $0.55 \pm 0.05$ & 0.71 \\
\hline 200 & $0.99 \pm 0.05$ & $0.52 \pm 0.01$ & $0.47 \pm 0.04$ & $0.56 \pm 0.06$ & 0.64 \\
\hline Average & 1.02 & 0.57 & 0.54 & 0.53 & \\
\hline $\mathrm{r}$ & 0.441 & -0.038 & -0.069 & $0.993^{* *}$ & 0.369 \\
\hline$L S D$ for: & \multicolumn{5}{|c|}{$\mathrm{Cu}$ dose $-0.04^{* *}$, substances application $-0.05^{* *}$, interaction $-0.09^{* *}$} \\
\hline \multicolumn{6}{|c|}{$\mathrm{C}: \mathrm{N}$ ratio } \\
\hline 0 & 12.29 & 19.06 & 14.88 & 16.06 & 15.57 \\
\hline 50 & 8.86 & 15.71 & 19.77 & 16.44 & 15.20 \\
\hline 100 & 8.36 & 13.35 & 17.65 & 16.13 & 13.87 \\
\hline 150 & 8.18 & 17.83 & 12.27 & 16.09 & 13.59 \\
\hline 200 & 9.39 & 17.02 & 16.60 & 14.34 & 14.34 \\
\hline Average & 9.42 & 16.60 & 16.23 & 15.81 & \\
\hline $\mathrm{r}$ & $-0.612^{*}$ & -0.143 & -0.227 & $-0.876^{* *}$ & $-0.760^{* *}$ \\
\hline$L S D$ for: & \multicolumn{5}{|c|}{$\mathrm{Cu}$ dose $-1.25^{* *}$, substances application $-1.40^{* *}$, interaction $-2.80^{* *}$} \\
\hline
\end{tabular}

Values are average \pm standard deviation; significant at ${ }^{* *} P \leq 0.01{ }^{*} P \leq 0.05$; n.s. - non-significant; $\mathrm{r}$ - correlation coefficient

(Tables 1-2). Compost, bentonite, and zeolite decreased the average content of total nitrogen by $45 \%, 48 \%$, and $48 \%$ and widened the $\mathrm{C}: \mathrm{N}$ ratio by $76 \%, 72 \%$, and $68 \%$, respectively, compared to the series without additions. They also increased the content of available magnesium, which ranged from $11 \%$ (compost) to $22 \%$ (bentonite) compared to the soils without amendments. The effect of the substances on the content of total organic carbon and available phosphorus and potassium was much smaller than on the content of total nitrogen, magnesium, and $\mathrm{C}: \mathrm{N}$ ratio. The trend of changes of these elements depended on the kind of substance. Zeolite reduced the content of organic carbon, available phosphorus, and potassium by $11-12 \%$ and bentonite, and that of organic carbon by $10 \%$ compared to the series with no additions. Compost increased the average content of available phosphorus by $6 \%$ and that of potassium by $12 \%$. Bentonite increased the content of available potassium by $8 \%$.

The PCA (Fig. 1) and the correlation coefficients (Table 3) revealed the significant relationship between the content of some elements and the C:N ratio, acidity, and other soil properties. Significant positive correlations were found to exist between:

- The content of total nitrogen and organic carbon and hydrolytic acidity of soil.

- The content of available phosphorus and potassium and the soil hydrolytic acidity. 
Table 2. Effect of copper contamination and neutralizing substances on content of available phosphorus, potassium, and magnesium in soil.

\begin{tabular}{|c|c|c|c|c|c|}
\hline Copper dose (mg/kg of soil) & Without amendments & Compost & Bentonite & Zeolite & Average \\
\hline \multicolumn{6}{|c|}{ Available phosphorus (mg/kg d.m.) } \\
\hline 0 & $98.8 \pm 2.0$ & $99.0 \pm 2.1$ & $90.5 \pm 1.5$ & $91.9 \pm 2.3$ & 95.1 \\
\hline 50 & $84.8 \pm 2.2$ & $116.9 \pm 0.7$ & $95.9 \pm 1.9$ & $87.8 \pm 1.4$ & 96.4 \\
\hline 100 & $99.5 \pm 0.4$ & $113.9 \pm 0.2$ & $95.9 \pm 1.2$ & $98.6 \pm 2.5$ & 102.0 \\
\hline 150 & $112.6 \pm 0.3$ & $111.0 \pm 0.8$ & $101.3 \pm 1.9$ & $95.3 \pm 2.0$ & 105.1 \\
\hline 200 & $118.7 \pm 2.0$ & $106.2 \pm 1.5$ & $112.8 \pm 1.6$ & $83.4 \pm 1.7$ & 105.3 \\
\hline Average & 102.9 & 109.4 & 99.3 & 91.4 & \\
\hline $\mathrm{r}$ & $0.808^{* *}$ & 0.191 & $0.934^{* *}$ & $-0.951^{* *}$ & $0.959^{* *}$ \\
\hline$L S D$ for: & \multicolumn{5}{|c|}{$\mathrm{Cu}$ dose $-7.39^{* *}$, substances application $-8.26^{* *}$, interaction $-16.52^{*}$} \\
\hline \multicolumn{6}{|c|}{ Available potassium (mg/kg d.m.) } \\
\hline 0 & $128.7 \pm 2.1$ & $137.2 \pm 3.0$ & $162.6 \pm 3.0$ & $99.1 \pm 3.0$ & 131.9 \\
\hline 50 & $124.5 \pm 3.0$ & $141.4 \pm 4.0$ & $132.9 \pm 2.0$ & $107.6 \pm 3.0$ & 126.6 \\
\hline 100 & $137.2 \pm 2.6$ & $145.6 \pm 0.9$ & $179.5 \pm 0.8$ & $128.7 \pm 1.2$ & 147.8 \\
\hline 150 & $147.7 \pm 3.0$ & $175.2 \pm 3.0$ & $137.2 \pm 1.2$ & $132.9 \pm 3.0$ & 148.3 \\
\hline 200 & $171.0 \pm 3.5$ & $192.2 \pm 3.0$ & $149.9 \pm 3.0$ & $158.3 \pm 2.0$ & 167.9 \\
\hline Average & 141.8 & 158.3 & 152.4 & 125.3 & \\
\hline $\mathrm{r}$ & $0.918^{* *}$ & $0.943^{* *}$ & -0.175 & $0.924^{* *}$ & $0.913^{* *}$ \\
\hline$L S D$ for: & \multicolumn{5}{|c|}{$\mathrm{Cu}$ dose $-7.69^{* *}$, substances application $-8.60^{* *}$, interaction $-17.20^{* *}$} \\
\hline \multicolumn{6}{|c|}{ Available magnesium (mg/kg d.m.) } \\
\hline 0 & $92.3 \pm 0.6$ & $129.1 \pm 1.1$ & $131.2 \pm 2.2$ & $95.7 \pm 2.9$ & 112.1 \\
\hline 50 & $88.5 \pm 0.8$ & $113.7 \pm 2.7$ & $131.2 \pm 2.1$ & $129.1 \pm 3.0$ & 115.6 \\
\hline 100 & $92.7 \pm 2.1$ & $114.1 \pm 2.1$ & $148.3 \pm 2.1$ & $135.5 \pm 3.1$ & 122.7 \\
\hline 150 & $127.0 \pm 3.1$ & $122.7 \pm 2.1$ & $122.7 \pm 4.2$ & $135.5 \pm 4.2$ & 127.0 \\
\hline 200 & $137.6 \pm 3.0$ & $119.3 \pm 4.2$ & $122.7 \pm 2.4$ & $125.2 \pm 3.9$ & 126.2 \\
\hline Average & 107.6 & 119.8 & 131.2 & 124.2 & \\
\hline $\mathrm{r}$ & $0.891^{* *}$ & -0.261 & -0.386 & $-0.866^{* *}$ & $0.951^{* *}$ \\
\hline$L S D$ for: & \multicolumn{5}{|c|}{$\mathrm{Cu}$ dose $-12.96^{* *}$, substances application $-14.22^{*}$, interaction - n.s. } \\
\hline
\end{tabular}

Values are average \pm standard deviation; significant at ${ }^{* *} P \leq 0.01{ }^{*} P \leq 0.05$; n.s. - non-significant; $r$ - correlation coefficient.

- The content of available potassium and the cation exchange capacity.

- The content of available magnesium and C:N ratio. Significant negative correlations were found to exist between:

- Total nitrogen and available magnesium.

- Total nitrogen and C:N ratio.

- The content of available phosphorus and $\mathrm{pH}$ and base saturation.

- The content of available magnesium and soil $\mathrm{pH}$.

- The C:N ratio and soil hydrolytic acidity (Table 3).

The relationships between the soil macroelements, especially between total nitrogen content, available phosphorus, potassium, and magnesium, and the C:N ratio were confirmed by PCA analysis (Fig. 1). In addition, the vectors perfectly reproduced the contents of available magnesium, total nitrogen, hydrolytic acidity, and base saturation, and it poorly reproduced the $\mathrm{C}: \mathrm{N}$ ratio - especially total organic carbon. The principal components represented in total $57.88 \%$ (including the first component at $30.15 \%$ and the second at $27.73 \%$ ). The data dispersion in Fig. 2 confirms the effects of compost, manure, and zeolite on soil properties, although it is difficult to claim beyond doubt which of these substances had the greatest effect. 
Table 3. Correlation coefficients (r) between content of elements and C:N ratio and some properties of soil.

\begin{tabular}{|c|c|c|c|c|c|c|}
\hline Factor & $\mathrm{C}_{\text {org }}$ & Total-N & $\mathrm{C}: \mathrm{N}$ ratio & $\mathrm{P}$ & $\mathrm{K}$ & $\mathrm{Mg}$ \\
\hline $\mathrm{pH}_{\mathrm{KCl}}$ & 0.084 & 0.210 & -0.230 & $-0.367^{*}$ & -0.292 & $-0.461^{* *}$ \\
\hline $\mathrm{HAC}$ & 0.061 & $0.365^{*}$ & $-0.380^{*}$ & $0.345^{*}$ & $0.457^{* *}$ & 0.186 \\
\hline $\mathrm{TEB}$ & -0.287 & -0.143 & -0.013 & -0.193 & 0.266 & 0.272 \\
\hline $\mathrm{CEC}$ & -0.264 & -0.058 & -0.096 & -0.110 & $0.358^{*}$ & 0.304 \\
\hline $\mathrm{BS}$ & -0.221 & $-0.376^{*}$ & 0.290 & $-0.380^{*}$ & -0.219 & 0.023 \\
\hline $\mathrm{C}_{\text {org }}$ & & $0.411^{* *}$ & -0.137 & 0.250 & 0.097 & -0.127 \\
\hline Total-N & & & $-0.930^{* *}$ & 0.127 & 0.035 & $-0.337^{*}$ \\
\hline C:N ratio & & & & -0.075 & -0.050 & $0.331^{*}$ \\
\hline P & & & & & $0.371^{*}$ & 0.055 \\
\hline K & & & & & & 0.266 \\
\hline
\end{tabular}

$\mathrm{pH}_{\mathrm{KCl}}-\mathrm{pH}$ in $1 \mathrm{M} \mathrm{KCl}, \mathrm{HAC}$ - hydrolytic acidity, TEB - total exchangeable bases, CEC - cation exchange capacity,

$\mathrm{BS}$ - base saturation; significant at ${ }^{* *} P \leq 0.01{ }^{*} P \leq 0.05 ; \mathrm{r}$ - correlation coefficient

Excessive amounts of copper in soil can disrupt the process of nutrient absorption by plants [3]. Since copper is firmly fixed in soil by organic substances, silty substances, and hydrated iron and aluminium oxides, it is important to increase the content of organic substances in soil as it has the greatest impact on its sorptive properties [22]. The application of organic and mineral substances with strong sorptive properties and adjusting soil $\mathrm{pH}$ reduces the bioavailability of copper and its toxicity to plants and soil microorganisms and increases the bioavailability of macroelements [14-15]. The correlation between $\mathrm{pH}$ and sorptive properties of soil and content of elements in soil was partly confirmed in our study. Particularly good results can be achieved

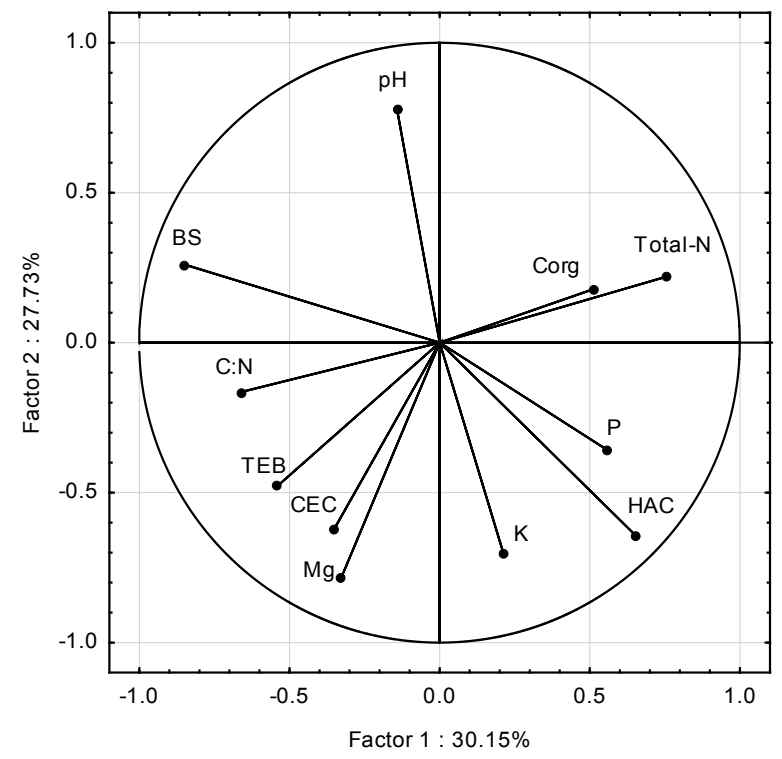

Fig. 1. Content of elements and $\mathrm{C}: \mathrm{N}$ ratio in the soils illustrated with the PCA method; key: vectors represent analyzed variable (content of $\mathrm{C}_{\text {org }}$, total- $\mathrm{N}$, available $\mathrm{P}, \mathrm{K}, \mathrm{Mg}$, and $\mathrm{C}: \mathrm{N}$ ratio). by applying organic matter to soil. The application of elements with organic substances caused an increase in these elements in soil. Bednarek et al. [23] used liquid manure and found the content of available phosphorus, potassium, and magnesium and organic carbon in soil to increase. According to Wright et al. [24], compost increases the content of phosphorus, potassium, and magnesium in soil. The application of compost to soil in an experiment carried out by Wyszkowski and Sivitskaya [25] increased the accumulation of organic carbon and available potassium in soil. Kondratowicz-Maciejewska and Kobierski [26] found that manure increased the content of available phosphorus, potassium, and magnesium, and its content was correlated to the content of organic carbon in soil, which was partly confirmed

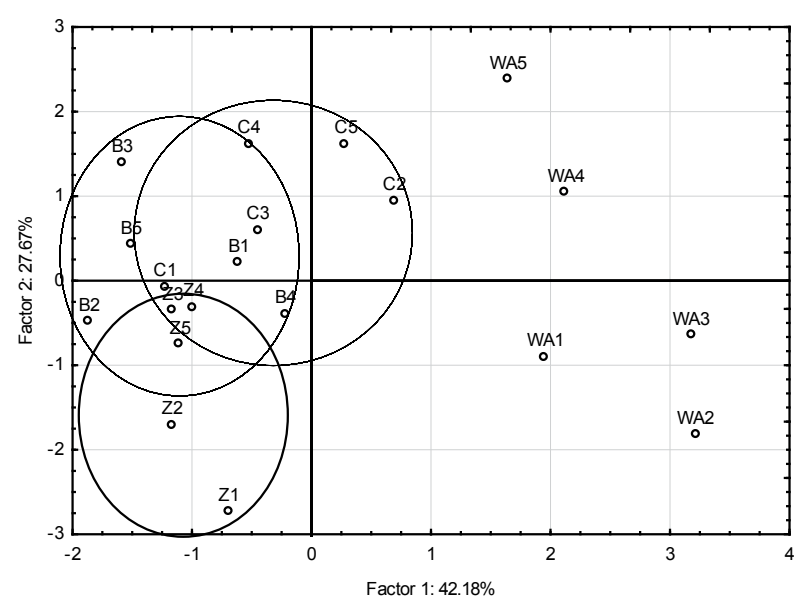

Fig. 2. Effect of neutralizing substances on content of macroelements and C: $\mathrm{N}$ ratio in the soils illustrated with the PCA method; key: points show soil samples with elements and C:N ratio (WA - without amendments, $\mathrm{C}$ - compost, B - bentonite, $\mathrm{Z}$ - zeolite; 1 - 0, 2 - $50 \mathrm{mg}, 3$ - $100 \mathrm{mg}, 4$ - $150 \mathrm{mg}, 5$ - $200 \mathrm{mg} /$ $\mathrm{kg}$ of soil). 
in this study. An increase of elements in soil contaminated with the highest doses of copper was correlated with the lowest maize yield. The uptake of elements by maize from soil contaminated with copper was lower than from control soil (without the application of copper).

Furthermore, Šimanský and Kováčik [27] found the content of organic carbon to be positively correlated to hydrolytic acidity and negatively correlated to the base saturation, which was not confirmed in this study. Moreover, as in this study, Kondratowicz-Maciejewska and Kobierski [26] found the content of available potassium to be correlated positively to the content of available magnesium. Wyszkowski and Sivitskaya [25] found bentonite to have a greater effect on the content of available forms of nutrients in soil than compost and zeolite. Bentonite increased the content of available phosphorus, potassium, and magnesium and zeolite only increased the content of available magnesium. Wyszkowski and Modrzewska [28] found the use of bentonite and zeolite to have a positive effect on the content of organic carbon, available phosphorus, and the $\mathrm{C}: \mathrm{N}$ ratio in soil. Moreover, bentonite increased the content of available potassium in soil. According to Ostrowska et al. [29], intensive humification and mineralisation of organic matter and an increase of elements in soil with $\mathrm{C}: \mathrm{N}$ ratio lower than 10, which was confirmed in this study in objects with copper contamination. A wide $\mathrm{C}: \mathrm{N}$ ratio has a negative effect on nitrogen content in soil because of uptake of this and another elements from soil solution. These relationships were observed in our study.

\section{Conclusions}

Contamination of soil with copper and the application of neutralizing substances had a significant effect on soil properties. Contamination with copper in the series without substances increased the content of total nitrogen and available phosphorus, potassium, and especially magnesium. Copper also widened the C:N ratio in soil. All of the amendments applied to the soil had the strongest effect on the content of total nitrogen and the $\mathrm{C}: \mathrm{N}$ ratio in soil. They reduced the content of total nitrogen and widened the $\mathrm{C}: \mathrm{N}$ ratio. Amendments also increased the content of available magnesium in soil. The effect of the substances applied to soil on the content of the other elements was significantly weaker, as it changed by up to $12 \%$.

\section{Acknowledgements}

Scientific research was financed by the Ministry of Science and Higher Education funds for statutory activity.

\section{Conflict of Interest}

The authors declare no conflict of interest.

\section{References}

1. NICHOLSON F.A., SMITH S.R., ALLOWAY B.J., CARLTON-SMITH C., CHAMBERS B.J. An inventory of heavy metals inputs to agricultural soils in England and Wales. Sci. Total Environ. 311 (1-3), 205, 2003.

2. HERCER M., WYSZKOWSKI M., MODRZEWSKA B. Impact of traffic on the content of trace elements in soils along State Road 53 (Poland). Fresen. Environ. Bull. 25 (3), 719, 2016.

3. WYSZKOWSKI M. Effect of contamination with copper and mineral or organic amendments on the content of trace elements in soil. Environ. Prot. Eng. 43 (4), 165, 2017.

4. FIJAŁKOWSKI K., KACPRZAK M., GROBELAK A., PLACEK A. The influence of selected soil parameters on the mobility of heavy metals in soils. Environ. Prot. Eng. 15 (1), 81, 2012.

5. BOROWIK A., WYSZKOWSKA J., KUCHARSKI J., BAĆMAGA M., BOROS-LAJSZNER E., TOMKIEL M. Sensitivity of soil enzymes to excessive zinc concentrations. J. Elem. 19 (3), 637, 2014.

6. DOMAŃSKA J., BADORA A., FILIPEK T. The sensitivity of Brassica napus ssp. oleifera to cadmium (Cd) and lead $(\mathrm{Pb})$ contamination at different $\mathrm{pH}$ of mineral and organic soils. J. Elem. 20 (1), 59, 2015.

7. SKWARYŁO-BEDNARZ B., BRODOWSKA M.S., BRODOWSKI R. Evaluating the influence of varied NPK fertilization on yielding and microelements contents at amaranth (Amaranthus cruentus L.) depending on its cultivar and plant spacing. Acta Sci. Pol.-Hortoru., 10 (4), 245, 2011.

8. TAPPERO R., PELTIER E., GRÄFE M., HEIDEL K., GINDER-VOGEL M., LIVI K.J., RIVERS M.L., MARCUS M.A., CHANEY R.L., SPARKS D.L. Hyperaccumulator Alyssum murale relies on a different metal storage mechanism for cobalt than for nickel. New Phytol. 175 (4), 641, 2007.

9. HANSCH R., MENDEL R.R. Physiological functions of mineral micronutrients $(\mathrm{Cu}, \mathrm{Zn}, \mathrm{Mn}, \mathrm{Fe}, \mathrm{Ni}, \mathrm{Mo}, \mathrm{B}, \mathrm{Cl})$. Curr. Opin. Plant Biol. 12, 259, 2009.

10. MANIVASAGAPERUMAL R., VIJAYARENGAN P., BALAMURUGAN S., THIYAGARAJAN G. Effect of copper on growth, dry matter yield and nutrient content of Vigna radiata (L.) Wilczek. J. Phytol. 3 (3), 53, 2011.

11. GAETKE L.M., CHOW-JOHNSON H.S., CHOW C.K. Copper: toxicological relevance and mechanisms. Arch. Toxicol. 88 (11), 1929, 2014.

12. ŻOŁNOWSKI A., BUSSE M., ZAJĄC P. Response of maize (Zea mays L.) to soil contamination with copper depending on applied contamination neutralising substances. J. Elem. 18 (3), 507, 2013.

13. PSZCZÓŁKOWSKI W., ROMANOWSKA-DUDA Z., PSZCZÓŁKOWSKA A., GRZESIK M., WYSOKIŃSKA $Z$. Application of phytoremediation in restoring sustainable development to the environment: economic and soil conditions comparative economic research. Central and Eastern Europe, 3, 37, 2012. 
14. KNOX A.S., SEAMAN J.C., MENCH M.J., VANGRONSVELD J. Remediation of metal and radionuclides-contaminated soils by in situ stabilization techniques. In: Environmental Restoration of MetalsContaminated Soils, Ed. I.K. Iskandar. Lewis, Boca Raton, FL, USA, 21, 2001.

15. BOLAN N., ADRIANO D., MANI S., KHAN A. Adsorption, complexation, and phytoavailability of copper as influenced by organic manure. Environ. Toxicol. Chem. 22, 450, 2003.

16. MUSZYŃSKI P., BRODOWSKA M.S. Effects of potassium, ammonium, and calcium chlorides on the sorption of metamitron in soil. Pol. J. Environ. Stud. 23 (6), 2125, 2014.

17. FENG N., DAGAN R., BITTON G. Toxicological approach for assessing the heavy metal binding capacity of soils. Soil Sediment Contam. 16, 451, 2007.

18. KOSIOREK M., WYSZKOWSKI W. Effect of neutralising substances on selected properties of soil contaminated with cobalt. J. Ecol. Eng. 17 (3), 193, 2016.

19. US-EPA METHOD 3051, Microwave assisted acid digestion of sediment, sludges, soils and oils, 1994.

20. LITYŃSKI T., JURKOWSKA H., GORLACH E. Chemical and agriculture analysis. PWN, Warszawa, 129, 1976 [in Polish].

21. DELL INC. Dell Statistica (data analysis software system), version 13, software.dell.com, 2016.

22. ŠIMANSKÝ V., POLLÁKOVÁ N. Soil organic matter and sorption capacity under different soil management practices in a productive vineyard. Arch. Agron. Soil Sci. 60 (8), 1145, 2014.
23. BEDNAREK W., DRESLER S., TKACZYK P., HANAKA A. Available forms of nutrients in soil fertilized with liquid manure and NPK. J. Elem. 17 (2), 169, 2012.

24. WRIGHT A.L., PROVIN T.L., HONS F.M., ZUBERER D.A., WHITE R.H. Compost source and rate effects on soil macronutrient availability under Saint Augustine Grass and Bermuda Grass Turf. Compost Sci. Utiliz. 15 (1), 22, 2007.

25. WYSZKOWSKI M., SIVITSKAYA V. Changes in the content of organic carbon and available forms of macronutrients in soil under the influence of soil contamination with fuel oil and application of different substances. J. Elem. 17 (1), 139, 2012.

26. KONDRATOWICZ-MACIEJEWSKA K., KOBIERSKI M. Content of available magnesium, phosphorus and potassium forms in soil exposed to varied crop rotation and fertilisation. J. Elem. 16 (4), 543, 2011.

27. ŠIMANSKÝ V., KOVÁČIK P. Long-term effects of tillage and fertilization on $\mathrm{pH}$ and sorption parameters of haplic Luvisol. J. Elem. 20 (4), 1033, 2015.

28. WYSZKOWSKI M., MODRZEWSKA B. Development of the selected properties of zinc-contaminated soil following an addition of neutralising substances. Polish J. Soil Sci. XLIX, 2, 101, 2016.

29. OSTROWSKA A., GAWLIŃSKI S., SZCZUBIAŁKA Z. Methods for analyzing and assessing the properties of soil and plants. Inst. Ochr. Środ., Warszawa, 333, 1991. [in Polish]. 
